\title{
The Effect of the Meaning and the Message as Reflected in the Matatu Register in Kenya Public Transport Sector
}

\author{
David Kihara \\ School of Social Sciences, Mount Kenya University \\ Email:dkihara@mku.ac.ke
}

\section{Doi:10.5901/mjss.2015.v6n2s1p435}

\section{Abstract}

\begin{abstract}
The main aim of this research was to analyze language in the communication between the matatu crew and the passengers. The study analyzed texts in the matatu register in the context of communication. The matatu service is vital to the passengers as it speeds up travel. It is therefore essential to understand language use in this register to understand how the participants communicate. An analysis of the matatu register in Swahili has not been carried out. Some scholars, for example Mbugua (2003), have studied the matatu culture from a sociological perspective. So far the researcher has not come across a linguistic analysis of this register. Such an analysis serves to provide the knowledge required to bring together the phonological, grammatical and lexical aspects to make communication effective.
\end{abstract}

Keywords: Analysis, Culture, Linguistics, Language, Communication

\section{Introduction}

Meaning is a real object that has a particular form like the reference, concept, truth and objective according to the grammar rules as well as societal ones. More importantly, in this study meaning has its use. In this section we will concentrate on the function of language and to interpret meaning as well as use. According to Davis and Gillon (2004), use refers to the purpose of a message as intended by the speaker. The view of meaning as use looks at a sentence and interprets it a new with a distinct meaning of a speech act.

We use language to meet certain objectives which we believe we will attain. Language use is equivalent to speech acts, where each act depends on the harmony between the participants, message, the setting as well as communication context. Yule (1996), states that a speech act can also be referred to as a language act or linguistic act. It is an act carried out by the production of an utterance where saying is the equal to acting. According to Yule, every statement brings forth an act.

A speech act is expected to have three features. The first one is a distinct utterance with clear literal meaning, among other requirements of grammar. The literal meaning carries the full explanation about something. Secondly, the act should aim at having a distinct effect especially informing, warning, persuading, consoling, amusing or even annoying. This means that the speaker has certain intentions.

Thirdly, the intended effect should be the basis of predicting the consequences especially changes in feelings, view, belief or expectations of the recipient. For example if intended to educate then consensus is necessary, for persuasion, acceptance and for queries and answers. In short, the effect will correspond with the expectations of the speaker which in turn corresponds to his intention. These three characteristics can be interpreted to show the interaction of three features: meaning in the utterance, the information intended and the effect of the information on the intended recipient.

The proponents of this theory were linguists with a social science bias such as sociology and anthropology. They interpret language to be a social heritage, communicative devices to be precise. This interpretation insists on the function of language in the societal relations and interactions. To advance this view, semantic features have been interwoven with those of pragmatics: a linguistic discipline that looks at the constraints of linguistic functions in the actual contexts of communication.

\section{Harmony in Communication}

Harmony in communication occurs where the message has positive effect by pleasing, persuading, consoling and 
satisfying the recipient. There is no misunderstanding between the participants. The speaker chooses a word that will bring about the effect intended to his audience as shown in this table:

\begin{tabular}{|c|c|c|c|}
\hline Speaker & Utterance & Answer & Effect on recipient \\
\hline Conductor & $\begin{array}{c}\text { Unaenda madam? (Madam, are you } \\
\text { going?) }\end{array}$ & Eeh. & She appeared pleased. \\
\hline Conductor & $\begin{array}{c}\text { Hoil Mwaenda mzee? (Hey! Old man, are } \\
\text { you going?) }\end{array}$ & Eeh. & They appeared convinced. \\
\hline Conductor & $\begin{array}{l}\text { Dawanol ngapi? (How much fare to } \\
\text { Dawanol stage?) }\end{array}$ & $\begin{array}{l}\text { Kidy moja kalia madam twende. (Ten shillings only, let's } \\
\text { go madam) }\end{array}$ & She appeared pleased. \\
\hline Conductor & $\begin{array}{l}\text { Mnaenda tao mzee. Gari ni ishirini kalieni. } \\
\text { (Old man, are you going to town? The fare } \\
\text { is twenty shillings.) }\end{array}$ & Tunaenda. (We are going.) & They appeared pleased. \\
\hline Passenger| & \begin{tabular}{|c|} 
Unabeba Phase one (Are you willing to \\
carry passengers alighting at Phase one?)
\end{tabular} & $\begin{array}{c}\text { Kalia bebwa ni kumi madam. (Yes, get i } \\
\text { only ten shillings.) }\end{array}$ & She looked pleased. \\
\hline Conductor & $\begin{array}{c}\text { Mnaenda? Nafasi ya wawili kalieni Boss } \\
\text { twende. (Are you going? There is space for } \\
\text { two. Get in Boss.) }\end{array}$ & Eeh. Kama una nafasi. (Yes, if you have space) & $\begin{array}{l}\text { They looked pleased and } \\
\text { convinced. }\end{array}$ \\
\hline Conductor & \begin{tabular}{|c|} 
Faster faster kuingia customer (please \\
hurry up and board the vehicle customer)
\end{tabular} & Sawasawa. (Ok.) & He lool \\
\hline Passenger & $\begin{array}{c}\text { Phase one? (How much fare to Phase } \\
\text { one?) }\end{array}$ & Kumi Boss. (Ten bob only.) & $\begin{array}{l}\text { He looked convinced and } \\
\text { happy. }\end{array}$ \\
\hline Passenger| & U-shop? (How much fare to U-shop?) & Ni kumi kalia Boss. (Fare is ten bob; & $\begin{array}{l}\text { He looked convinced and } \\
\text { happy. }\end{array}$ \\
\hline Passenger| & $\begin{array}{l}\text { Hii gari inakaa kwa stage sana. (This } \\
\text { vehicle overstays at the stage.) }\end{array}$ & $\begin{array}{c}\text { Tulia mama hii hula chapuchapu. Wawili tu twende. (Be } \\
\text { patient woman, this vehicle fills up quickly. Two more } \\
\text { passengers and then we leave) }\end{array}$ & $\begin{array}{c}\text { The conductor appeared to get } \\
\text { angry. The passenger looked } \\
\text { satisfied. }\end{array}$ \\
\hline Passenger & K. U ngapi? (How much to K.U?) & Namba nne kalia twende. (Forty shillings, let's go.) & $\begin{array}{c}\text { The passenger looked happy } \\
\text { and convinced. }\end{array}$ \\
\hline Passenger & $\begin{array}{c}\text { Kenyatta Road? (how much to Kenyatta } \\
\text { Road?) }\end{array}$ & Kumi ingia twende. (Ten bob, let's go.) & $\begin{array}{l}\text { The passenger looked happy } \\
\text { and convinced }\end{array}$ \\
\hline Passenger & Allsopps how much? & Thelathini kalia twende. (Thirty shillings, let's go.) & $\begin{array}{l}\text { The passenger looked happy } \\
\text { and convinced }\end{array}$ \\
\hline Passenger| & Ngapi Ngara? (How much to Ngara?) & Selasa, ingia twende. (Thirty & $\begin{array}{l}\text { The passenger looked happy } \\
\text { and convinced. }\end{array}$ \\
\hline Passenger & $\begin{array}{c}\text { Roundaa ni ngapi ? (How much to Ngara } \\
\text { stage) }\end{array}$ & $\begin{array}{c}\text { Ni kumi. Hata Phase one ni kumi. (Its t } \\
\text { Phase one) }\end{array}$ & They looked convinced. \\
\hline Passenger| & Ati ngapi? (How much fare again?) & $\begin{array}{c}\begin{array}{c}\text { Twenty Allsopps njiani kumi. (Twenty bob to Allsopps and } \\
\text { ten on the way.) }\end{array} \\
\end{array}$ & $\begin{array}{l}\text { The passenger looked } \\
\text { convinced. }\end{array}$ \\
\hline Passenger| & $\begin{array}{c}\text { Mlango kubwa? (How much fare to Mlango } \\
\text { kubwa?) }\end{array}$ & $\begin{array}{l}\text { Kumi faster faster kalau mbele. (It's ten bob, hurry up } \\
\text { there are policemen ahead.) }\end{array}$ & $\begin{array}{l}\text { The passenger looked } \\
\text { convinced. }\end{array}$ \\
\hline Passenger & B.P? (How much to B.P?) & Kumi. (Ten bob.) & $\begin{array}{l}\text { The passenger looked happy } \\
\text { and convinced. }\end{array}$ \\
\hline Passenger & $\begin{array}{c}\text { Garrissa Lodge? (How much to Garrissa } \\
\text { Lodge?) }\end{array}$ & Kumi. (Ten bob.) & $\begin{array}{c}\text { The passenger looked happy } \\
\text { and convinced }\end{array}$ \\
\hline Passenger & Wapita Ngara? (Are you going via Ngara?) & Eeh Muranga Road njia. (Yes, via Muranga Road.) & $\begin{array}{l}\text { The passenger looked } \\
\text { satisfied. }\end{array}$ \\
\hline Passenger & $\begin{array}{c}\text { Nafasi ya wawili? (Is there sitting space for } \\
\text { two ?) }\end{array}$ & Ingieni viti iko. (Get in, the seats are there.) & They looked happy. \\
\hline Passenger| & $\begin{array}{c}\text { Wapita hospitali ? (Are you going via the } \\
\text { hospital) }\end{array}$ & $\begin{array}{c}\text { Eeh pamoja na Technical kalia. (Yes, even via Technical, } \\
\text { get in.) }\end{array}$ & The passenger looked pleased. \\
\hline Passenger & Njia gani? (Which route?) & Pilot njia. (The Pilot route.) & $\begin{array}{c}\text { The passenger looked pleased } \\
\text { and satisfied }\end{array}$ \\
\hline
\end{tabular}

From this table, we get to see the different effects of various speech acts. When the conductor stated unaenda madam he expected an answer. When the commuter answered in the affirmative Eeh, this answer clearly pleased the conductor because the commuter had agreed to get into the matatu and thus increase the number of passengers in the matatu. The conductor was also pleased because other passengers boarded his vehicle especially on noting that they were many passengers in the matatu. The conductor was happy his work had been made easier. The passenger on the other hand was happy when called madam by the conductor as well as being informed the fare to Roysambu was thirty shillings.

When the conductor called out Hoi! Mwaenda mzee he expected an answer. The commuters answer Eeh pleased the conductor because the elderly commuter and his two pals agreed to board the vehicle. The passengers were persuaded to board the matatu after they learnt the fare to Allsopps was twenty shillings (namba mbili).

On uttering Dawanol ngapi the passenger expected an answer. The conductor's answer kidy moja kalia madam 
(ten shillings only, let's go madam) pleased the commuter especially when She heard the fare was ten shillings only, the answer given in a polite manner. Similarly the use of the word madam indicates the use of polite language, something that encouraged the passenger to happily board the vehicle. The passenger is happy she was invited properly and politely. On the other hand the conductor was happy the commuter agreed to board his vehicle.

When the conductor stated Mnaenda tao mzee he expected an answer from the elderly commuter. The commuter's answer Tunaenda made him happy because he would get a total of four extra passengers as the elderly commuter was accompanied by his three pals. Similarly, the commuters were happy because of the polite appeal to board the vehicle and the fact that the fare is twenty shillings to the city. The use of the polite reference to an old man mzee also pleased the commuters because it indicated the conductor respected their pal.

The commuter expected a reply from the conductor to be an adjunct to the utterance Unabeba Phase one? The conductor's answer Kalia bebwa ni kumi madam pleases her as she realizes the vehicle will drop her at her preferred destination and for ten shillings as fare. She is also happy to be addressed with respect as madam. On the other hand, the conductor was happy the passenger agreed to board his vehicle which will add more passengers.

When conductor uttered Mnaenda? Nafasi ya wawili kalieni Boss twende he expected an answer. The commuter's answer Eeh kama una nafasi pleased the conductor since the two remaining seats in the matatu would now be occupied. On the other hand, this utterance by the conductor persuaded the passengers to board the vehicle. They were persuaded when they heard there were only two empty seats remaining and also being addressed as Boss by the conductor. The use of the word boss to refer to the passengers is a clear indication that he respects and values them.

When the conductor uttered faster faster kuingia customer, he expected his customers to board the vehicle quickly. The passenger's positive answer sawasawa pleased the conductor because the passenger obeyed and saved time. At the same time, the passenger was happy despite being urged to hurry up and board the vehicle. What made him happy was being addressed as customer by the conductor; an indication that the conductor valued and respected him.

On uttering Phase one? the commuter expected the conductor to inform him the fare he would pay to Phase one. His answer: Kumi boss persuaded the commuter. He was persuaded on hearing that the fare to Phase one was ten shillings only. He was also happy by the use of the word Boss because it indicated the conductor accorded him a high status and thus respected him.

When the commuter uttered U-shop? He expected an answer from the conductor about the fare he would pay to U-shop. The conductor's answer ni kumi kalia boss convinced him. He was persuaded on hearing that the fare to U-shop was ten shillings. He was also happy because the utterance was a good invitation. He was also pleased on being called Boss, an indication that he was valued and respected.

When a passenger (woman) complains about a particular matatu saying hii gari inakaa kwa stage sana expected the conductor to understand her and ensure the vehicle moves on as it had overstayed at the boarding station. This utterance affected the conductor psychologically as he took it to mean the passenger was inciting the others. He was clearly annoyed, judging by his facial expression. To ensure she did not alight, the conductor tried to convince her to be patient saying Tulia mama hii hula chapuchapu. Wawili tu twende. He assures her that his vehicle usually fills up fast and she settled down.

When the commuter uttered K.U ngapi? he expected an aswer. The conductor replied, saying Namba nne kalia (forty bob, get in), the customer was persuaded. The conductor managed to convince the passenger to board the vehicle by charging him the amount of fare he wanted. The passenger was also pleased by the conductor's invitation. Similarly, the conductor was happy the commuter boarded his vehicle. The act whereby the conductor convinces the commuter to board his matatu and to pay the fare demanded by the conductor is a sign that there was some knowledge that bound them together. The conductor and the commuter have a common experience or cooperate in communication.

Following the utterance Kenyatta Road? the commuter expected an answer from the conductor. The conductor's answer Kumi ingia twende pleases and persuades him. He was happy that he was invited properly by the conductor. He was convinced to board the vehicle because the fare was low. On the other hand, the conductor was pleased when the commuter agreed to board his matatu. The conductor's attempt to convince the passenger and the passenger being persuaded to board the vehicle and pay ten shillings fare was an indication they shared some common information. That is they cooperated in communication.

When the commuter enquires: Allsopps how much? he expected an answer from the conductor. The conductors answer thelathini kalia twende pleased the commuter and convinced him to board the vehicle. His good invitation pleased the commuter. The conductor convinced the passenger to board the vehicle by charging him thirty shillings fare to Allsopps. The conductor was also happy the passenger boarded his matatu.

When the commuter uttered ngapi Ngara he expected to be answered by the conductor about the fare to Ngara. The conductor's answer selasa, ingia twende (thirty shillings, get in) pleased and persuaded the commuter. He was 
happy because of the good invitation. He was also persuaded because the thirty shillings fare appealed to him. On the other hand, the conductor was happy the passenger boarded his matatu.

On uttering Roundaa ni ngapi the passenger expects the conductor to tell how much the fare to Roundaa was. The conductor's answer; Ni kumi. Hata Phase one kumi persuaded him and others headed to Phase one. There was a struggle at the door in an attempt to board the vehicle, which pleased the conductor immensely.

When the passenger stated ati ngapi? he expected the conductor to inform him about the fare to Roundaa. The conductor answered: twenty Allsopps njiani kumi. This convinced the commuter to board the vehicle because he provided the clarification expected. The conductor's explanation was satisfactory.

The passenger expected an answer on the fare to Mlango Kubwa from the conductor on enquiring Mlango kubwa? The conductor's answer kumi faster faster kalau mbele convinced the commuter to board the vehicle especially after the conductor had agreed to charge him ten shillings fare despite the risk of the conductor and driver being arrested by the traffic police for picking passengers at an undesignated area.

When the passenger uttered B.P? he expected the conductor to inform him how much fare he would pay to B.P. The conductor answeres kumi pleases him and convinces him to board the vehicle. That the fare is ten shillings pleases and persuades the passenger.

On uttering Garissa Lodge? the commuter expected the conductor to inform him how much the fare to Garissa was. The conductor's answer, that the fare is ten shillings pleased the commuter. It also persuaded him to board the vehicle.

When the passenger stated wapita Ngara? he expected the conductor to tell him whether the vehicle would go via Ngara or not. When the conductor answered in the affirmative Eeeh Murang'a Road njia, the passenger was satisfied since he knew for sure that a vehicle using Muranga Road will certainly pass through Ngara.

When the commuters asked: nafasi ya wawili they expected the conductor to inform them whether there would be seats for the both of them. When the conductor answered ingieni viti iko (Get in, the seats are available), they were pleased because before it had appeared like there was only space for one.

The passenger's question wapita hospitali indicated he expected an answer if the vehicle would go via the hospital or not. The conductor's answer eeh pamoja na Technical pleased him especially from the explanation offered. He was satisfied because he knew the road to Technical and the hospital was the same.

When the commuter asked njia gani he expected the conductor to tell the vehicle was headed to Makongeni. He expected to be told it would use the Bidco route or the Pilot one. Th conductor's answer Pilot njia pleased and satisfied him since he had been waiting for a matatu plying the Pilot route to Makongeni.

It is quite clear that the conductor's actions in persuading the passengers and the passengers getting persuaded to board the vehicle and pay the fare stated by the conductor is a sign of a shared experience. The conductor knows that for the passenger to accept what they say they have to be persuaded. The passengers on the other hand know that the conductors seek to persuade them especially through attractive fares so that they can board their vehicles. That is to mean that the conductors and passengers share a similar experience and cooperate in communication.

From these, it is clear harmony in communication occurs when the message has a positive impact. Positive effects are those that bring about the success of communication; that is those that please instead of annoying, which persuade or cheer the listener's feelings in one way or another. Positive effect is brought about by careful selection of words among the matatu crew and the passengers in any communication.

\section{Discords in Communication}

Sometimes, speech acts do convey meaning that has a negative impact on the recipients. The impacts affect the success of communication and are brought about by inappropriate selection of words that end up upsetting and demeaning the recipients as shown in the following table:

\begin{tabular}{|c|c|c|c|}
\hline Speaker & Utterance & $\begin{array}{c}\text { Effect on the } \\
\text { recipient }\end{array}$ \\
\hline Conductor & $\begin{array}{c}\text { Shuka haraka haraka ndio wale kalao (Alight quickly the police officers } \\
\text { are near) }\end{array}$ & $\begin{array}{c}\text { Usiniharakishe. (Do not hurry me up) } \\
\text { looked upset. }\end{array}$ \\
\hline Conductor & Faster faster wa haraka (Hurry up) & Utatuangusha. (You will make us fall) & They looked upset. \\
\hline Driver & Faster, ndio hao kalao. (Hurry up I can see police officers nearing) & Hi! Polepole (Hey! Stop the hurry) & They got annoyed. \\
\hline Conductor & Chunga hizo deree (driver, beware of those vehicles) & $\begin{array}{c}\text { Naziona. Beba watu. (I can see them. Look } \\
\text { for passengers.) }\end{array}$ & He looked annoyed. \\
\hline Driver & Funga hiyo gate tena. (Close that door again) & Nini kibaya. (What is wrong?) & He looked upset. \\
\hline Conductor & $\begin{array}{c}\text { Mbele dereva zimekuja chukua wawili mbele. (Driver, speed up the } \\
\text { vehicles are catching up so that we can get at least two passengers) }\end{array}$ & $\begin{array}{c}\text { He looked } \\
\text { surprised. }\end{array}$ \\
\hline
\end{tabular}




\begin{tabular}{|c|c|c|c|}
\hline Passenger| & Wacha nishuke na jam (let me alight since we are stuck in a jam) & $\begin{array}{l}\text { Huoni kalao? (There are policemen here, } \\
\text { you can't see them?) }\end{array}$ & He looked upset. \\
\hline Conductor & $\begin{array}{r}\text { Kujeni niwalipe kwa nyingine (Con } \\
\text { pay yc }\end{array}$ & $\begin{array}{c}\text { Hujatufikisha wewe. (You did not take us to } \\
\text { our destination) }\end{array}$ & They \\
\hline Driver & $\begin{array}{r}\text { Fanya faster hakuna stage hapa. }(\mathrm{H} \\
\text { at an undesic }\end{array}$ & $\begin{array}{r}\text { Hakuna kwa } \\
\text { undes }\end{array}$ & $\mathrm{Hel}$ \\
\hline Driver & Na hii jam nayo. (This jam & Tumekwama sasa. (We are stuck in it) & $\begin{array}{l}\text { jected } \\
\text { t. }\end{array}$ \\
\hline Driver & $\begin{array}{r}\begin{array}{r}\text { Waambie wajifunge mishipi ni kuk } \\
\text { is trou }\end{array} \\
\end{array}$ & Jifunge mkanda. (Fasten the seat belts) & $\begin{array}{l}\text { The } \\
\text { su }\end{array}$ \\
\hline ger & We kondaa lete change. (C & ina. $(1)$ & He look \\
\hline Conductor & shuka ni bure. (We don't c & Polepole kijana. & \\
\hline Conductor & zee & $\begin{array}{l}\text { Umeweka hiyo } \\
\text { delayed in }\end{array}$ & pset. \\
\hline Conductor & Toa twenty six. Faster mamii. (D & $\begin{array}{l}\text { Wacha nishuke polepole. (Let me alight } \\
\text { slowly.) }\end{array}$ & She loc \\
\hline and & $\begin{array}{c}\text { Simamisha watoto mama au unawalipia? (Tell the children to s } \\
\text { or are you paying fare for them) }\end{array}$ & Watasimama. (They will stand.) & annoyed. \\
\hline
\end{tabular}

As shown in this table, the conductor expected the passenger to alight quickly when he said shuka haraka haraka ndio wale kalao. The expectation arose from the fact that the statement was cautionary. The conductor was reluctant to open the door in the middle of the road for the passenger to alight lest he and the driver be arrested by the traffic police for breaking traffic rules. The passenger did not seem to understand the risk facing the matatu crew and therefore was annoyed by the conductor's statement. His annoyance was evident in the answer he gave: usiniharakishe. His answer upset the conductor who expected the passenger to understand the risk at hand.

The conductor's utterance faster faster wa haraka is a command. He expected the passengers to alight quickly. He made this statement because there were many other vehicles that were almost catching up with them. If the passengers alighted slowly, the other vehicles would certainly catch up and pick passengers ahead. The passengers were annoyed by his statement since they didn't understand why they were being rushed to alight yet they were not hurried up when boarding. The conductor was quite respectful when ushering them into the vehicle. Their annoyance was evident in their answer: utatuangusha. This answer upset the conductor who expected the passenger to understand that other vehicles were almost catching up with his vehicle so they needed to alight quickly.

The driver's utterance faster, ndio hao kalao was cautionary. He therefore expected the conductor to request the passengers to board the vehicle quickly. He cautioned the conductor that there were traffic policemen ahead. He expected the conductor to open the door so that the passengers could board quickly before the traffic police spotted them picking up passengers in the middle of the road. The driver's statement annoyed the conductor as well as the passengers. The passenger's annoyance was signaled by their answer: Hil Polepole. This answer also annoyed the driver because he expected the passengers to understand the impending danger. The conductor on the other hand was annoyed because the driver was rushing him yet he knew the vehicle was not full. The passengers did not understand why they were being rushed to board the vehicle yet there were others which they could board at leisure. The driver uttered those words to caution since he knew the risk ahead. He knew if the policemen saw him picking passengers in the middle of the road he would be arrested for breaking traffic rules.

The conductor cautions the driver by telling him: chunga hizo dinga deree (Take care lest those vehicles pass you). He then expected the driver to drive off quickly because many vehicles were after them. He knew if the vehicles caught up with them, they would compete for the passengers. He expected the driver to quickly drive off to reach the bus stop ahead before the other vehicles and pick the passengers there. But the conductor's statement annoyed the driver who answered: naziona. Beba watu. (I can see them. Look for passengers.) The driver was upset since the conductor assumed he was blind to the fact that there were vehicles racing to catch up with them. The driver's answer similarly annoyed the conductor since he felt the driver was disobedient and one to bring losses. But the conductor did not intend to annoy the driver, he want to caution the driver since if the vehicles after them caught up with them, they would face an uphill task filling the vehicle with passengers. They would also take longer to reach their destination.

The driver's statement to the conductor: funga hiyo gate tena was to caution him that he had not closed the door properly. He expected the conductor to open the door and then close it properly. This statement annoyed the conductor who felt the driver was undermining his experience. His annoyance was evident in his statement: nini kibaya? His answer annoyed the driver who felt the conductor was disobedient and did not understand the risk he was exposing himself as well as the passengers to. The caution was given because if the door fell open, an accident was possible since the conductor or passengers were likely to fall off the vehicle and be injured. 
The conductor intended to caution the driver through the statement: mbele dereva zimekuja chukua wawili mbele. (Hurry up there are vehicles racing to catch up with us, you pick at least two passengers). He expected the driver to speed up as they were being followed by speeding matatus. The driver looked surprised as he didn't expect so many vehicles to be racing to catch up with his matatu.

The passenger made a request by stating: wacha nishuke na jam. The passenger expected the conductor to open the door so that he could alight as the matatu was caught up in a traffic jam. The passenger's statement annoyed the conductor since there were many traffic policemen who were trying to deal with the gridlock. His annoyance was evident in his answer: huoni kalao? (You can't see the policemen?). His answer annoyed the passenger who didn't understand why could not alight yet the vehicles were not moving. The conductor was upset since there was the likelihood of the policemen spotting him opening the door for passengers to alight in the middle of the road. This would lead to his being arrested for breaking traffic rules. He expected the passenger to be cognizant of that fact.

When the conductor stated: kujeni niwalipie kwa nyingine he expected the passengers to alight and board the other vehicle. The passengers refused to dismount, complaining that they were yet to reach their destination. Their fury was evident in their faces but they finally agreed to dismount and their fare was paid for in the other vehicle. They were annoyed and some clicked their tongues. Their answer: hujatufikisha wewe annoyed the conductor who did not understand why the passengers refused to alight yet he had promised to pay their fare in the alternative vehicle.

When the driver was informed by the conductor through a knock on the window using a coin that passengers wanted to alight, he reacted by saying: fanya faster hakuna stage hapa. He expected the passengers to alight quickly. His statement however annoyed the passenger who wondered why he was being told that was an undesignated area. His annoyance was evident in his rejoinder: hakuna kwa nini. He was also upset by the order that he alights quickly. The driver on the other hand was annoyed by the passenger's retort since he knew that that was clearly an undesignated area.

On realizing they were stuck in a traffic jam, the driver grumbled, saying:na hii jam nayo. He didn't expect any traffic jam. His statement made the conductor lose hope and he was upset. This was evident in his reply: tumekwama sasa. The conductor did not expect any jam and wanted them to get to their packing bay, collect passengers and be on their way. The conductor's reply disheartened the driver.

When the driver asked the conductor to tell the passengers to fasten their seat belts saying: wajifunge mishipi $n i$ kubaya mbele he expected all passengers to fasten the seat belts. His statement jolted the conductor and the passengers who started looking for their seat belts. They were clearly affected by the information, fearing arrest by the police.

When the passenger said: we kondaa lete change he expected the conductor to give him his change. The conductor's answer: ngoja sina annoyed him because the conductor had for long not given him his change yet he had given the other passengers. The conductor was also annoyed by the passenger's statement, especially the term kondaa. He felt the passenger did not respect him, he had belittled him by calling him kondaa. He was forced to tell him to wait even though he would soon be alighting in the next stage. When the passenger realized the conductor was upset, he tried to remind him he was alighting at the market which was the next stage.

When the conductor stated kushuka ni bure, fanya haraka mathy, he expected the passengers to alight quickly. The conductors statement annoyed the elderly female passenger who felt at her advanced age it was disrespectful to be urged by someone his son's age to alight quickly. Her annoyance was evident in her answer: polepole kijana. On the other hand, the passengers answer annoyed the conductor who did not understand why the passenger was insisting on alighting slowly yet there were vehicles racing to catch up with them.

When he said shika mzee the conductor expected the passenger to be happy to get back his change. The passenger however was upset since he felt the reason the conductor had delayed his change was because he was elderly. The conductor had given all other passengers their change promptly. The passenger's rejoinder: umeweka hiyo change sana annoyed the conductor because he felt the old man was not patient. The conductor did not have enough change and had relied on another passenger to provide loose change for the old man's two hundred shilling note.

When the conductor uttered: toa twenty six faster mamii, he expected the passenger to alight quickly. This statement annoyed the passenger. Her annoyance was evident in her retort: wacha nishuke polepole. Her rejoinder upset the conductor who didn't understand why the passenger wanted to alight slowly yet there were vehicles behind them racing to catch up.

By uttering simamisha watoto mama au unawalipia the conductor expected the female passenger to make her children stand so that the adults could take up the seats. This statement annoyed the passenger who felt the conductor took her for a fool who did not understand the state of affairs. She had told her children to sit down as the vehicle was almost empty. She meant to tell them to stand once passengers got in. The passenger's answer: watasimama upset the conductor because he did not understand why the mother could not tell her children to stand at that particular time. Their 
sitting down made the vehicle appear full. The passengers would peep and ask if there was sitting space before entering, something that annoyed the conductor.

From the explanation given, it is clear discord in communication occurs where the information conveyed appears to have a negative impact. Negative impacts do not contribute to the success of communication; they annoy and dishearten the participants. These negative impacts are brought by poor choice of words which end up annoying and belittling the participants.

\section{Conclusion}

This chapter has explicated that whenever we use language we aim to meet some objective by affecting our listeners in various ways such as persuading, cautioning, advising, informing or enlightening. Language use is likened to speech acts, each act depending on the harmony between the participants, the information, and the communication context and setting. The meaning of these speech acts has different impacts on the recipients. These impacts are both psychological and mental. The impacts of language use in the matatu register are joy, anger, persuasion, encouragement, solace, disillusionment, cheerfulness and surprise.

It has also been noted that the conductor's acts to persuade the passengers to board the vehicles and agree to pay the fare stated was indicative of the fact that both the passengers and the conductor shared some common knowledge between them. The conductors know that for the passengers to accept their word, they have to persuade them. On the other hand, the passengers are aware that the conductors try to entice them using the fare to make them board their vehicles. That means the conductor and the passengers enjoy the same experience in the tenets of communication.

It has been elucidated that harmony in communication occurs where there is positive impacts. Positive impacts bring the success of communication; that is those that do not annoy but cheer, persuade and entertain the feelings of the listener in one way or another. It has been shown that positive impacts are brought about by careful choice of words by the matatu crew and passengers. On the other hand, discord in communication is brought about by negative impacts. These are the ones that block the success of communication, those that annoy and dishearten. They are brought about by poor choice of words which end up annoying and belittling the participants.

\section{References}

Aloo, S. 2002. 'Uchanganuzi wa Matangazo ya Redio na Televisheni: Mtazamo wa Kipragmatiki'. Unpublished M.A Research Thesis: Kenyatta University, Nairobi.

Beaugrande, R. and Dressler 1981. Introduction to Text Linguistics. New York: Longman.

Brown, G. and Yule 1983. Discourse Amalysis. Cambridge: Cambridge University Press.

Collinge, N. E. (Ed) 1990. An Encyclopedia of Language. London: Routledge.

Cook, G. 1989. Discourse. New York: Oxford University Press.

Davis, S. and Gillon 2004. Semantics. Oxford: Oxford University Press.

Deuchar, M. 2003. Bilingual Acquisistion: Theoretical Implications of a Case. New York: Oxford University Press.

Dijk, V.T. 1977. Text and Context: Explorations in the Semantics and Pragmatics of Discourse. London: Longman.

Edmondson, W. 1981. Spoken Discourse. London: Longman.

Fasold R. 1984. The Sociolinguistics of Society. Oxford: Basil Blackwell.

Goody, E. N. 1978. Towards a Theory of Questions: Questions and Politeness Strategies in Social Interactions. Cambridge: Cambridge University Press.

Habwe, J.H. 1989. Elements of Pragmatic Discourse among the Mvita People. Unpublished M.A Thesis, University of Nairobi, Nairobi.

Halliday. M.A.K. et al 1964. The Linguistic Science and Language Teaching. London: Longman.

Halliday, M.A.K. 1985. An Introduction to Functional Grammar. London: Edward Arnold.

Halliday, M.A.K. 1994. Functional Grammar $2^{\text {nd }}$ ed. London: Edward Arnold.

Inyani, S.K. 1992. 'Uchambuzi wa Fani katika Utenzi wa Vita vya Wadachi Kutamalaki Mrima'. Unpublished M.A Thesis, Moi University, Eldoret.

Kiai, A.W. 1996. 'A Discourse Analysis of Educational Radio Programs to Farmers Adaptation Register'. Unpublished M.A Thesis, University of Nairobi, Nairobi.

Kitsao, J. 1975. 'A Stylistic Approach Adapted for the Study of Kiswahili Prose Texts. Unpublished M.A Thesis: University of Nairobi, Kenya.

Kitsao, J. 1982. 'An investigation of Themes in Kiswahili Literature: An Application of Stylostatistics to Chosen Texts'. Unpublished PhD Thesis: University of Nairobi.

Lanza, E. 2004. Language Mixing in Infant Bilingualism: A Sociolinguistic Perspective. New York: Oxford University Press.

Levinson S.C. 1983. Pragmatics. Cambridge: Cambridge University Press. 
Malmakjear, K. 1991. The Linguistics Encyclopedia. Amsterdam: John Benjamins Publishing Company.

Mbaabu, I. 1992. Sarufi ya Kiswahili. Nairobi : Longman Kenya.

Mbugua, M. 2003. 'Identity Politics in Nairobi Matatu Folkrole'. Unpublished PhD Thesis: Hebrew University of Jerusalem.

Michira, J.N 1993. 'Uchanganuzi wa Kimtindo wa Lugha ya Wachuuzi na Lugha ya Matangazo ya Biashara Redioni'. Unpublished M.A Thesis: University of Nairobi.

Milroy, L. 1987. Observing and Analysing Natural Languages. New York: Basil Blackwell.

Ndung'u V. 2001. 'Uchanganuzi Usemi katika Sajili ya Dini: Sifa Bainifu za Lugha ya Mahubiri'.Unpublished M.A Thesis: Kenyatta University, Nairobi.

Neyole, N.E. 2003. 'Umatini katika Vichekesho vya "Redykyulass"'. Unpublished M.A Thesis: Kenyatta University, Nairobi.

Njeri, T. 1997. 'Cohesion and Compactness in Compositions Written by Kenyan Urban Primary School Children'. Unpublished M.A Thesis: Kenyatta University, Nairobi.

Njogu, k. and Chimera 1999. Ufundishaji wa Fasihi: Nadharia na Mbinu. Nairobi: Jomo Kenyatta Foundation.

Njue, J.G. 1989. 'Muwala katika Kiswahili: Umuhimu wake katika Uchambuzi wa Ngano za Waswahili'. Unpublished M.A Thesis: University of Nairobi.

Richards, J. et al 1985. A Longman Dictionary of Applied Linguistics. London: Longman.

Salkie, R. 1995. Text and Discourse Analysis. London: Routledge.

Saville-Troike, M. 1989. The Ethnography of Communication: An Introduction. Oxford: Basil Blackwell.

Trauth, G. and Kazzazi 1996. Routledge Dictionary OF Language and Linguistics. London: Routledge.

TUKI 2004: Kamusi ya Kiswahili Sanifu. Dar es Salaam: Oxford University Press.

Walya, E. 1996. 'Kenya Banking Discourse structure: Strategies' and their Effects on Banking Interaction'. Unpublished M.A Thesis: Kenyatta University.

Wamitila, K. W. 2004. Kichocheo cha Fasihi: Simulizi na Andishi. Nairobi: Focus Books.

Wendell, V.H. 1992. Dictionary of Concepts in Literary Criticism and Theory. New York: Greenwood Press.

Yule, G.N. 1996. Pragmatics. Oxford: Oxford University Press. 